\title{
RETINAL NERVE FIBER LAYER THICKNESS IN GLAUCOMA PATIENTS TREATED WITH MULTIPLE INTRAVITREAL ANTI-VEGF (BEVACIZUMAB) INJECTIONS
}

\author{
Andrijana Kopić1,2, Dubravka Biuk ${ }^{1,2}$, Josip Barać, ${ }^{1,2}$, Maja Vinković1,2, \\ Tvrtka Benašić ${ }^{1,2}$ and Vlatko Kopić ${ }^{2,3}$
}

\begin{abstract}
${ }^{1}$ Clinical Department of Ophthalmology, Osijek University Hospital Centre; ${ }^{2}$ School of Medicine, Josip Juraj Strossmayer University; ${ }^{3}$ Department of Maxillofacial and Oral Surgery, Osijek University Hospital Centre, Osijek, Croatia
\end{abstract}

\begin{abstract}
SUMMARY - Over the past decade, intravitreal injections of anti-VEGF agents have been widely used and intensively developed as a treatment option for many ophthalmological indications. Due to its availability and low cost, the most frequently used anti-VEGF agent is bevacizumab. This type of therapy is often indicated in patients with exudative age-related macular degeneration (ARMD) and diabetic macular edema (DME). If, in addition to these two conditions, patients have a diagnosis of primary open angle glaucoma (POAG), they also present with optic nerve head (ONH) retinal nerve fiber layer (RNFL) thinning. The aim of this prospective study was to establish whether administering bevacizumab to patients with POAG leads to additional reduction of RNFL thickness. The study included 60 patients divided into two groups. First group comprised the eyes of patients with exudative ARMD and POAG, whereas second group comprised the eyes of patients with DME and POAG, all treated with bevacizumab. Control group comprised the fellow eye of each involved patient, which was not treated with bevacizumab. In a period of one year, all patients underwent optical coherence tomography (OCT) measurements of ONH RNFL thickness. The results of all patients were compared between the two study groups and then with control group results. Study results showed a decrease of RNFL in both groups of patients. Comparison of these two groups of patients after one year revealed a statistically more significant decrease in RNFL thickness in the second group (DME + POAG).
\end{abstract}

Key words: Intravitreal injections; Vascular endothelial growth factor A; Bevacizumab; Retinal degeneration; Macular edema; Diabetes mellitus; Glaucoma, primary open angle; Croatia

\section{Introduction}

Intravitreal injections of anti-vasoendothelial growth factor (anti-VEGF) agents have become one of the most advanced ophthalmological treatment options over the past ten years. Anti-VEGF agents are

Correspondence to: Andrijana Kopic, MD, Clinical Department of Ophthalmology, Osijek University Hospital Centre, Europska avenija 14-16, HR-31000 Osijek, Croatia

E-mail: andrijanakopic@gmail.com

Received August 4, 2017, accepted August 31, 2017 used for various ophthalmological disorders, including exudative form of age-related macular degeneration $(\mathrm{ARMD})^{1}$, diabetic retinopathy and diabetic macular edema (DME) $)^{2}$, retinopathy of prematurity ${ }^{3,4}$, central and branch retinal vein occlusion ${ }^{5}$, neovascular glaucoma, tumors ${ }^{6}$, etc. There are various anti-VEGF medications available on the market, bevacizumab (Avastin, Genentech, San Francisco, USA) being the predominant one in Croatia. Bevacizumab is a humanized recombinant monoclonal IgG antibody that binds and inhibits all VEGF-A isoforms. Originally approved 
for the treatment of colorectal carcinoma, bevacizum$a b$ is used in ophthalmology as an off-label medication for intravitreal administration with favorable results in clinical practice. Anti-VEGF agents bind and block VEGF on the surface of various blood and lymphatic vessels. VEGF is secreted in response to ischemia and is responsible for inducing angiogenesis and neovascularization. There are two types of macular degeneration, i.e. dry or non-exudative form, characterized by the presence of drusen and geographic atrophy ${ }^{7}$, and wet or exudative form, characterized by the presence of choroidal neovascularizations.

The wet or exudative form of ARMD is one of the most common indications for intravitreal administration of bevacizumab. The patients frequently complain of a sudden onset of significantly decreased visual acuity. Later stages of this disorder include cicatrization (scar formation) of the affected macular area, which leads to permanent loss of central visual acuity. In the absence of any other eye disorders, the patient's peripheral sight remains undamaged. Senile macular degeneration is diagnosed by performing ophthalmoscopic examination via optical coherence tomography (OCT), OCT angiography, and at times, fluorescein angiography ${ }^{8,9}$.

Diabetic macular edema most often accompanies diabetic retinopathy and is one of the most common diabetes-related eye complications. DME is also diagnosed by performing ophthalmoscopic examination via OCT, OCT-A and fluorescein angiography $^{8}$.

Primary open angle glaucoma (POAG) is a chronic optic neuropathy, which, if left untreated, leads to a decreased retinal nerve fiber layer (RNFL) thickness, as well as peripheral and subsequently central visual field loss. To make an accurate diagnosis, and also to confirm disease progression, it is important to perform regular measurements of optic nerve head $(\mathrm{ONH})$ RNFL thickness with OCT scans, as well as regular computerized automated perimetry ${ }^{8}$.

Patients suffering from POAG who are diagnosed with exudative ARMD or DME are at a risk of losing central visual acuity and peripheral vision. The aim of this study was to establish whether intravitreal administration of bevacizumab leads to additional decrease in RNFL thickness in patients already diagnosed with POAG and decreased thickness of ONH RNFL.

\section{Subjects and Methods}

Sixty patients over the age of 18 , both male and female, were enrolled in this prospective study and divided into two groups. Due to their primary disorder, all of these patients would have been treated with intravitreal bevacizumab regardless of the study. The first group comprised 30 eyes of patients suffering from exudative ARMD and POAG. The second group comprised 30 eyes of patients suffering from DME and POAG. All eyes included in this study received a minimum of 4 intravitreal bevacizumab injections over the course of 12 months.

Control group comprised the fellow eye of each involved patient, also diagnosed with POAG, but not treated with bevacizumab prior to or during the study. Each subject received a participant information sheet, as well as a special form containing information on the type of therapy, medical procedure to be performed, general risks of the procedure, success rates and guidelines for early post-administration period, which is routinely handed out to every patient scheduled for bevacizumab injections at our Department. Each subject was given the approval issued by the Medicines Committee of the Osijek University Hospital Center concerning the administration described.

All subjects underwent OCT scanning and measurement of the mean and per quadrant (temporal, nasal, inferior and superior) ONH RNFL thickness (Copernicus HR, Optopol, Zawiercie, Poland) prior to the administration of bevacizumab, and then at 1, 3, 6 and 12 months following the administration of bevacizumab. During this time, each subject received a minimum of four intravitreal bevacizumab doses. For the purpose of this examination, mydriasis was achieved by applying 1 drop of tropicamide and 1 drop of phenylephrine hydrochloride to the eye.

As part of primary disorder treatment, all subjects received intravitreal injections of $1.25 \mathrm{mg}$ bevacizumab (Avastin, Genentech, San Francisco, USA) at least four times or more, at intervals of 4 to 6 weeks. Intravitreal injections were administered in sterile environment of an operating room, always by the same ophthalmologist.

Each group of subjects included a control group, which comprised the fellow eye of each involved patient, which was not injected with bevacizumab. Each measurement included both eyes. 
Table 1. Descriptive statistics and t-test results $(A R M D+P O A G)$

\begin{tabular}{|c|c|c|c|c|c|c|}
\hline Time point & Eye & $\begin{array}{l}\text { Arithmetic mean } \\
(\mu \mathrm{m})\end{array}$ & $\begin{array}{l}\text { Standard } \\
\text { deviation }(\mu \mathrm{m})\end{array}$ & $\begin{array}{l}\text { Difference } \\
(\mu \mathrm{m})\end{array}$ & $\mathrm{t}$ & $\mathrm{p}$ \\
\hline Month 0 & $\begin{array}{l}\text { Injected } \\
\text { Noninjected }\end{array}$ & $\begin{array}{l}77.27 \\
76.46\end{array}$ & $\begin{array}{l}12.48 \\
16.40\end{array}$ & 0.81 & 0.213 & 0.832 \\
\hline Month 12 & $\begin{array}{l}\text { Injected } \\
\text { Noninjected }\end{array}$ & $\begin{array}{l}76.20 \\
75.03\end{array}$ & $\begin{array}{l}12.53 \\
16.39\end{array}$ & 1.17 & 0.310 & 0.758 \\
\hline
\end{tabular}

*Statistically significant at the level $\mathrm{p}<0.05 ; \mathrm{ARMD}+\mathrm{POAG}=$ age-related macular degeneration + primary open angle glaucoma

Patients with other ocular pathologies, such as advanced cataract stage, glaucoma patients with poorly regulated intraocular pressure (IOP), patients with amblyopia, glaucoma patients with a cup to disc ratio over 0.8 , patients with reduced corneal transparency, patients with blurred vitreous body, patients who underwent retinal laser photocoagulation, vitrectomized patients and patients who had to receive anti-VEGF agents in both eyes prior to or during this study due to their primary disorder were excluded.

\section{Statistical analysis}

Both descriptive and inferential statistics were used on data analysis. Dependent samples t-test was used to establish significance of variations in nerve fiber thickness within the same patient group at the beginning of treatment and 12 months after the treatment. Independent samples t-test was used to analyze variations in the mean nerve fiber thickness in the patients' diseased eyes (experimental group) and control eyes (control group). The mean values of nerve fiber thickness with $95 \%$ confidence intervals were presented graphically. All variations with $\mathrm{p}<0.05$ were considered to be statistically significant.

\section{Results}

The study enrolled 60 subjects divided into two groups. First group enrolled 30 patients diagnosed with exudative form of ARMD and POAG, 12 male and 18 female, mean age 67.37( \pm 11.93$)$ years. They received a mean of 6.27 bevacizumab injections intravitreally in the treated eye during the 12 -month period. Second group of patients included 30 patients diagnosed with DME and POAG, 13 male and 17 female, mean age $64.5( \pm 11.22)$ years. Patients enrolled in this group were treated with a mean of 6.5 bevacizumab injections during the 12-month follow up period.

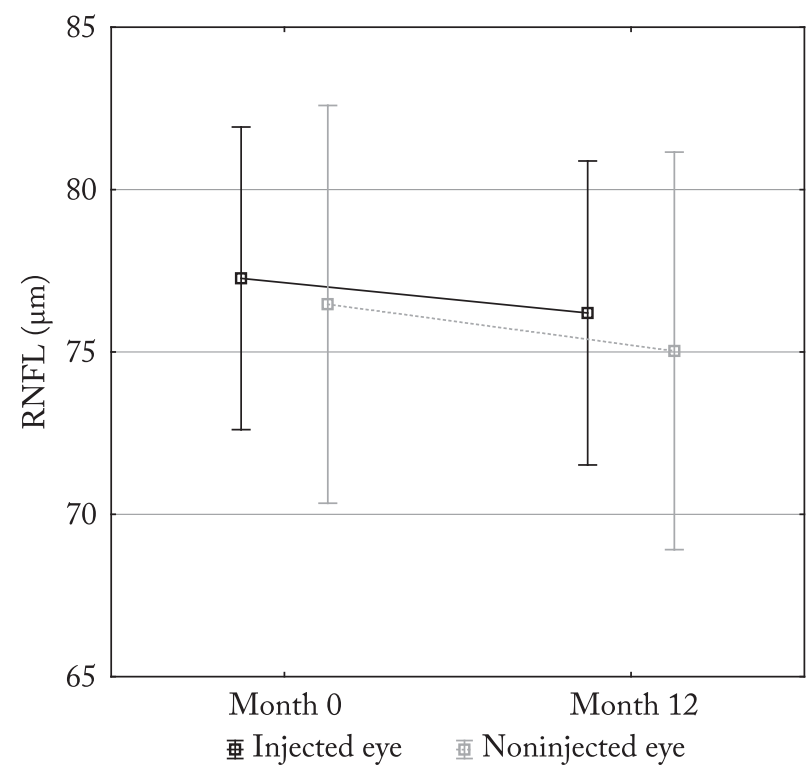

$\mathrm{RNFL}=$ retinal nerve fiber layer; $\mathrm{ARMD}+\mathrm{POAG}=$ age-related macular degeneration + primary open angle glaucoma

Fig. 1. Arithmetic means of RNFL (ARMD + POAG) in injected and noninjected eyes with $95 \%$ confidence intervals at the beginning and after 12 months.

In the first group of patients (ARMD + POAG), RNFL thickness decreased during 12 months from $77.27 \mu \mathrm{m}( \pm 12.48)$ to $76.20 \mu \mathrm{m}( \pm 12.53)$, mean 1.07 $\mu \mathrm{m}$, on the treated eye (Table 1). Analysis of the fellow eye showed that RNFL decreased during 12 months from $76.46 \mu \mathrm{m}( \pm 16.40)$ to $75.03 \mu \mathrm{m}( \pm 16.39)$, mean $1.43 \mu \mathrm{m}$ (Table 1). Comparison of the treated and fellow eyes yielded no statistically significant difference in RNFL thickness decrease between the two groups of eyes (Table 1, Fig. 1). RNFL thickness measured in the quadrants of treated eyes also decreased statistically significantly, which was most pronounced in temporal $(\mathrm{T})$ quadrant, $-1.13 \mu \mathrm{m}$, and least in nasal 
Table 2. Descriptive statistics parameters and results of dependent samples t-test (injection eyes) (ARMD + POAG) - quadrants

\begin{tabular}{|c|c|c|c|c|c|c|}
\hline Quadrant & Time point & $\begin{array}{l}\text { Arithmetic mean } \\
(\mu \mathrm{m})\end{array}$ & $\begin{array}{l}\text { Standard } \\
\text { deviation }(\mu \mathrm{m})\end{array}$ & $\begin{array}{l}\text { Difference } \\
(\mu \mathrm{m})\end{array}$ & $\mathrm{t}$ & $\mathrm{p}$ \\
\hline $\mathrm{T}$ & $\begin{array}{l}\text { Month } 0 \\
\text { Month } 12\end{array}$ & $\begin{array}{l}65.86 \\
64.73 \\
\end{array}$ & $\begin{array}{l}14.17 \\
14.08 \\
\end{array}$ & 1.13 & 9.109 & $0.000^{*}$ \\
\hline S & $\begin{array}{l}\text { Month } 0 \\
\text { Month } 12\end{array}$ & $\begin{array}{l}92.10 \\
91.73 \\
\end{array}$ & $\begin{array}{l}17.64 \\
17.71\end{array}$ & 0.43 & 3.612 & $0.001^{*}$ \\
\hline $\mathrm{N}$ & $\begin{array}{l}\text { Month } 0 \\
\text { Month } 12\end{array}$ & $\begin{array}{l}66.20 \\
65.77\end{array}$ & $\begin{array}{l}11.64 \\
11.53\end{array}$ & 0.37 & 4.176 & $0.000^{*}$ \\
\hline I & $\begin{array}{l}\text { Month } 0 \\
\text { Month } 12 \\
\end{array}$ & $\begin{array}{l}93.33 \\
92.27 \\
\end{array}$ & $\begin{array}{l}18.88 \\
18.83 \\
\end{array}$ & 1.06 & 7.443 & $0.000^{*}$ \\
\hline
\end{tabular}

*Statistically significant at the level $\mathrm{p}<0.05 ; \mathrm{ARMD}+\mathrm{POAG}=$ age-related macular degeneration + primary open angle glaucoma; $\mathrm{T}$ = temporal; $\mathrm{S}=$ superior; $\mathrm{N}$ = nasal; $\mathrm{I}$ = inferior

Table 3. Descriptive statistics parameters and results of dependent samples t-test (noninjection eyes) (ARMD + POAG) - quadrants

\begin{tabular}{|c|c|c|c|c|c|c|}
\hline Quadrant & Time point & $\begin{array}{l}\text { Arithmetic mean } \\
(\mu \mathrm{m})\end{array}$ & $\begin{array}{l}\text { Standard } \\
\text { deviation }(\mu \mathrm{m})\end{array}$ & $\begin{array}{l}\text { Difference } \\
(\mu \mathrm{m})\end{array}$ & $\mathrm{t}$ & $\mathrm{p}$ \\
\hline $\mathrm{T}$ & $\begin{array}{l}\text { Month } 0 \\
\text { Month } 12\end{array}$ & $\begin{array}{l}64.27 \\
63.27\end{array}$ & $\begin{array}{l}13.16 \\
13.17 \\
\end{array}$ & 1.00 & 6.021 & $0.000^{*}$ \\
\hline S & $\begin{array}{l}\text { Month } 0 \\
\text { Month } 12\end{array}$ & $\begin{array}{l}92.36 \\
91.83 \\
\end{array}$ & $\begin{array}{l}19.60 \\
19.43 \\
\end{array}$ & 0.53 & 2.719 & $0.011^{*}$ \\
\hline $\mathrm{N}$ & $\begin{array}{l}\text { Month } 0 \\
\text { Month } 12 \\
\end{array}$ & $\begin{array}{l}68.53 \\
68.03 \\
\end{array}$ & $\begin{array}{l}13.04 \\
13.25 \\
\end{array}$ & 0.50 & 3.042 & $0.005^{*}$ \\
\hline I & $\begin{array}{l}\text { Month } 0 \\
\text { Month } 12\end{array}$ & $\begin{array}{l}91.57 \\
90.67\end{array}$ & $\begin{array}{l}23.43 \\
23.34\end{array}$ & 0.90 & 5.137 & $0.000^{*}$ \\
\hline
\end{tabular}

*Statistically significant at the level $\mathrm{p}<0.05 ; \mathrm{ARMD}+\mathrm{POAG}=$ age-related macular degeneration + primary open angle glaucoma; $\mathrm{T}=$ temporal; $\mathrm{S}=$ superior; $\mathrm{N}=$ nasal; $\mathrm{I}=$ inferior

(N) quadrant, $-0.37 \mu \mathrm{m}$ (Table 2). At 12 months, the group of fellow eyes also showed a statistically significant decrease in RNFL thickness according to quadrants. The greatest decrease in RNFL thickness was recorded in temporal $(\mathrm{T})$ quadrant, $-1.00 \mu \mathrm{m}$, and the least in nasal (N) quadrant, $-0.50 \mu \mathrm{m}$ (Table 3). Comparison of the treated and fellow eyes in this group of patients yielded no statistically significant difference in RNFL thickness decrease during the 12-month period either.

In the second group of patients (DME + POAG), RNFL thickness decreased during 12 months from $84.90 \mu \mathrm{m}( \pm 16.41)$ to $81.10 \mu \mathrm{m}( \pm 16.08)$, mean 3.80 $\mu \mathrm{m}$, on the treated eye (Table 4). In the fellow eye, RNFL decreased during 12 months from $92.30 \mu \mathrm{m}$
$( \pm 13,60)$ to $90.03 \mu \mathrm{m}( \pm 13.52)$, mean $2.27 \mu \mathrm{m}$ (Table 4). Comparison of the treated and fellow eyes yielded a statistically significant difference in RNFL thickness decrease between these two groups of eyes (Table 4, Fig. 2). RNFL thickness measured in the quadrants of treated eyes also decreased statistically significantly, which was most pronounced in inferior (I) quadrant, $-3.46 \mu \mathrm{m}$, and least in nasal $(\mathrm{N})$ quadrant, $-1.37 \mu \mathrm{m}$ (Table 5). At 12 months, the group of fellow eyes also showed a statistically significant decrease in RNFL thickness according to quadrants. The greatest decrease in RNFL thickness was recorded in inferior (I) quadrant, $-2.97 \mu \mathrm{m}$, and the least in nasal $(\mathrm{N})$ quadrant, $-0.83 \mu \mathrm{m}$ (Table 6). Comparison of the treated and fellow eyes in this group of patients yielded no statisti- 
Table 4. Descriptive statistics and t-test results (DME + POAG)

\begin{tabular}{|c|c|c|c|c|c|c|}
\hline Time point & Eye & $\begin{array}{l}\text { Arithmetic mean } \\
(\mu \mathrm{m})\end{array}$ & $\begin{array}{l}\text { Standard } \\
\text { deviation }(\mu \mathrm{m})\end{array}$ & $\begin{array}{l}\text { Difference } \\
(\mu \mathrm{m})\end{array}$ & $\mathrm{t}$ & $\mathrm{p}$ \\
\hline Month 0 & $\begin{array}{l}\text { Injected } \\
\text { Noninjected }\end{array}$ & $\begin{array}{l}84.90 \\
92.30\end{array}$ & $\begin{array}{l}16.41 \\
13.60\end{array}$ & -7.40 & -1.902 & 0.062 \\
\hline Month 12 & $\begin{array}{l}\text { Injected } \\
\text { Noninjected }\end{array}$ & $\begin{array}{l}81.10 \\
90.03\end{array}$ & $\begin{array}{l}16.08 \\
13.52\end{array}$ & -8.93 & -2.329 & $0.023^{*}$ \\
\hline
\end{tabular}

*Statistically significant at the level $\mathrm{p}<0.05 ; \mathrm{DME}+\mathrm{POAG}=$ diabetic macular edema + primary open angle glaucoma

cally significant difference in RNFL thickness decrease during 12 -month period.

\section{Discussion}

With longer life expectancy, the number of patients diagnosed with ARMD is increasing. ARMD is the third cause of blindness in developed countries ${ }^{10}$. While no appropriate therapy has yet been found for the dry form of ARMD, the exudative or wet form of ARMD is successfully treated with intravitreal injections of anti-VEGF agents. DME is the most common cause of visual impairment in patients with diabetes mellitus ${ }^{11}$ and it is also treated with anti-VEGF agents. Numerous studies, experimenta ${ }^{12}$ and clinical, investigated safety and possible side effects of intravitreal anti-VEGF therapy, especially bevacizumab ${ }^{13-16}$.

When discussing RNFL thickness safety, previous studies showed that multiple intravitreal bevacizumab injections did not decrease RNFL thickness ${ }^{17-20}$. Clinical studies mostly enrolled patients with $\mathrm{ARMD}^{21}$, whereas patients with other indications for intravitreal

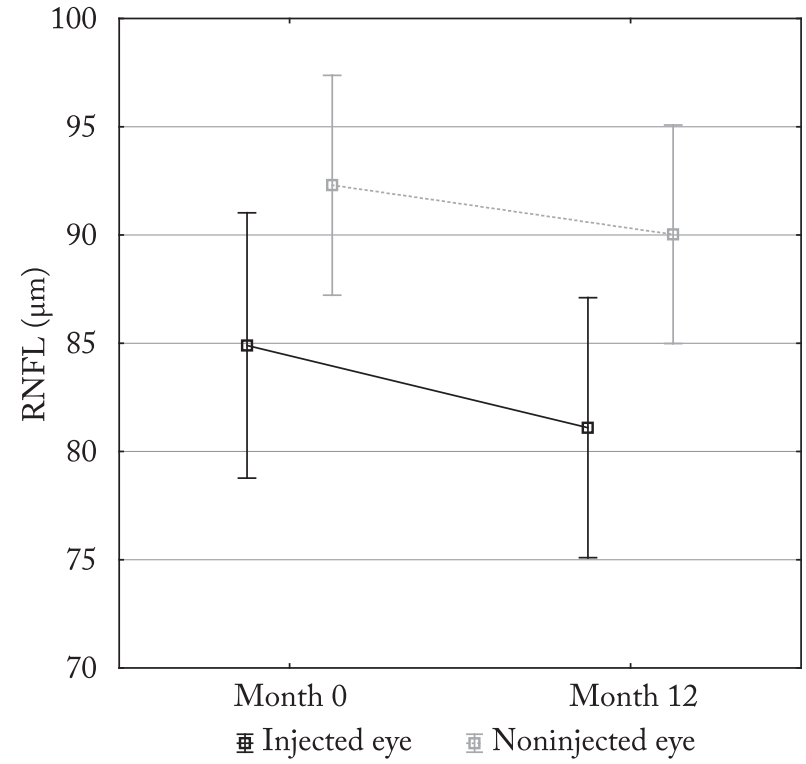

$\mathrm{RNFL}=$ retinal nerve fiber layer; $\mathrm{DME}+\mathrm{POAG}=$ diabetic macular edema + primary open angle glaucoma

Fig. 2. Arithmetic means of RNFL (DME + POAG) of injected and noninjected eyes with $95 \%$ confidence intervals at the beginning and after 12 months.

Table 5. Descriptive statistical parameters and results for dependent samples t-test (injection eyes) (DME +POAG) - quadrants

\begin{tabular}{|c|c|c|c|c|c|c|}
\hline Quadrant & Time point & $\begin{array}{l}\text { Arithmetic mean } \\
(\mu \mathrm{m})\end{array}$ & $\begin{array}{l}\text { Standard } \\
\text { deviation }(\mu \mathrm{m})\end{array}$ & Difference $(\mu \mathrm{m})$ & $\mathrm{t}$ & $\mathrm{p}$ \\
\hline $\mathrm{T}$ & $\begin{array}{l}\text { Month } 0 \\
\text { Month } 12\end{array}$ & $\begin{array}{l}55.10 \\
52.80 \\
\end{array}$ & $\begin{array}{l}10.29 \\
10.22 \\
\end{array}$ & 2.30 & 12.752 & $0.000^{*}$ \\
\hline S & $\begin{array}{l}\text { Month } 0 \\
\text { Month } 12\end{array}$ & $\begin{array}{l}98.63 \\
96.90\end{array}$ & $\begin{array}{l}22.69 \\
22.48\end{array}$ & 1.73 & 7.901 & $0.000^{*}$ \\
\hline $\mathrm{N}$ & $\begin{array}{l}\text { Month } 0 \\
\text { Month } 12 \\
\end{array}$ & $\begin{array}{l}67.07 \\
65.70 \\
\end{array}$ & $\begin{array}{l}12.92 \\
13.05 \\
\end{array}$ & 1.37 & 2.700 & $0.011^{*}$ \\
\hline I & $\begin{array}{l}\text { Month } 0 \\
\text { Month } 12\end{array}$ & $\begin{array}{l}95.73 \\
92.27\end{array}$ & $\begin{array}{l}20.13 \\
20.05\end{array}$ & 3.46 & 12.268 & $0.000^{*}$ \\
\hline
\end{tabular}

*Statistically significant at the level $\mathrm{p}<0.05 ; \mathrm{DME}+\mathrm{POAG}=$ diabetic macular edema + primary open angle glaucoma; $\mathrm{T}=$ temporal; $\mathrm{S}=$ superior; $\mathrm{N}=$ nasal; $\mathrm{I}=$ inferior 
Table 6. Descriptive statistics parameters and results of dependent samples t-test (noninjection eyes) (DME +POAG) - quadrants

\begin{tabular}{|c|c|c|c|c|c|c|}
\hline Quadrant & Time point & $\begin{array}{l}\text { Arithmetic mean } \\
(\mu \mathrm{m})\end{array}$ & $\begin{array}{l}\text { Standard } \\
\text { deviation }(\mu \mathrm{m})\end{array}$ & $\begin{array}{l}\text { Difference } \\
(\mu \mathrm{m})\end{array}$ & $\mathrm{t}$ & $\mathrm{p}$ \\
\hline $\mathrm{T}$ & $\begin{array}{l}\text { Month } 0 \\
\text { Month } 12\end{array}$ & $\begin{array}{l}58.83 \\
57.20\end{array}$ & $\begin{array}{l}9.25 \\
9.49\end{array}$ & 1.63 & 7.350 & $0.000^{*}$ \\
\hline S & $\begin{array}{l}\text { Month } 0 \\
\text { Month } 12\end{array}$ & $\begin{array}{l}108.60 \\
107.17\end{array}$ & $\begin{array}{l}17.04 \\
17.31\end{array}$ & 1.43 & 6.738 & $0.000^{*}$ \\
\hline $\mathrm{N}$ & $\begin{array}{l}\text { Month } 0 \\
\text { Month } 12\end{array}$ & $\begin{array}{l}68.96 \\
68.13 \\
\end{array}$ & $\begin{array}{l}9.84 \\
9.72 \\
\end{array}$ & 0.83 & 4.805 & $0.000^{*}$ \\
\hline I & $\begin{array}{l}\text { Month } 0 \\
\text { Month } 12\end{array}$ & $\begin{array}{l}105.00 \\
102.03\end{array}$ & $\begin{array}{l}20.09 \\
19.87\end{array}$ & 2.97 & 2.423 & $0.000^{*}$ \\
\hline
\end{tabular}

*Statistically significant at the level $\mathrm{p}<0.05 ; \mathrm{DME}+\mathrm{POAG}=$ diabetic macular edema + primary open angle glaucoma; $\mathrm{T}=$ temporal; $\mathrm{S}=$ superior; $\mathrm{N}$ = nasal; $\mathrm{I}$ = inferior

anti-VEGF therapy were less frequently included ${ }^{20}$. Any kind of glaucoma disease in patients on antiVEGF therapy was an exclusion criterion for enrolling patients in all of these studies. Most researchers explain it with previously decreased RNFL thickness due to glaucomatous damage.

On designing this study, we were interested in assessing the effect of multiple intravitreal bevacizumab injections on RNFL thickness in POAG patients. VEGF is known to be an angiogenic and neurotropic factor, therefore long-term suppression of neurotropic cytokines could theoretically explain additional RNFL thickness decrease in patients receiving anti-VEGF agents $^{22,23}$. It is also known that intravitreal therapy can sometimes cause transient or sustained IOP elevation $^{24-29}$. These IOP spikes can be potentially dangerous for additional damage of RNFL in patients with POAG.

Results in the first group of patients with ARMD and POAG showed that there was no significant difference in the decrease of RNFL thickness between the injected and noninjected eyes during 12-month follow up period ( $p=0.758)$. These results are consistent with those reported from other similar studies, including electrophysiological ${ }^{30}$ and clinical studies, which could not demonstrate any toxic effect of intravitreal bevacizumab on RNFL thickness. When we analyzed quadrant changes in RNFL thickness during 12-month follow up, we found temporal quadrant to show greatest thinning and nasal quadrant smallest thinning. Both eye groups, injection and noninjection, showed the same pattern of RNFL thickness changes, without statistically significant difference between them. The main limiting factor in this group was the relatively small number of patients enrolled due to the low prevalence of patients diagnosed with exudative form of ARMD and POAG.

In the second group of patients diagnosed with DME and POAG, 12-month follow up period showed a statistically significant difference in overall RNFL thickness between the groups of injected and noninjected eyes $(p=0.023)$. Analysis of quadrant changes of RNFL yielded no statistically significant difference at 12-month follow up, with greatest change recorded in the inferior quadrant. These results indicated that the effect of multiple intravitreal bevacizumab injections on RNFL thickness may have occurred in this group of patients. Comparison of these results with the first group of patients (ARMD + POAG) revealed that the mean decrease of RNFL thickness was greater in this group, suggesting DME as part of diabetic retinopathy changes as another risk factor for RNFL thinning, i.e. inner retinal ischemia ${ }^{31-34}$. This group of patients had several limiting factors. As for the first group, the number of enrolled patients was small because of all inclusion criteria and small prevalence of patients with these two diseases. In addition, this group of patients usually had initial diabetic macular changes on one eye, but with time they developed the same condition on the fellow eye and needed intravitreal treatment for the fellow eye too and that was the main reason why the follow up period was not longer. 
Results of this prospective study show that we cannot be sure that multiple intravitreal bevacizumab injections are safe for RNFL thickness in all indications for which patients receive them. Patients with POAG and other types of glaucoma are at a particularly high risk because any additional RNFL thinning is dangerous and any IOP elevation, even at short terms, must be prevented. We should also keep in mind that some of the diseases that require chronic intravitreal bevacizumab therapy, such as DME and retinal vein occlusions, through inner retinal ischemia, additionally decrease RNFL thickness over time. It is necessary to conduct more studies of similar design with larger numbers of POAG patients and longer follow up period to determine safety and possible influence of bevacizumab and other anti-VEGF agents on RNFL thickness.

In conclusion, our results showed a statistically significant loss of retinal nerve fibers in both groups of patients, i.e. those with ARMD + POAG and DME + POAG, during 12-month follow up. Considering that these patients already have compromised RNFL thickness, the possible changes of RNFL thickness caused by chronic bavacizumab injections are not negligible. Thus, it appears reasonable to monitor IOP elevations and RNFL thickness more closely during intravitreal treatment in patients with POAG and especially DME + POAG.

\section{References}

1. Schmidt-Erfurth U, Chong V, Loewenstein A, Larsen M, Sowied E, Schlingemann R, Eldem B, Mones J, Richard G, Bandellio F. Guidelines for the management of neovascular age-related macular degeneration by the European Society of Retina Specialists (EURETINA). Br J Ophthalmol. 2014 Sep;98(9):1144-67. doi: 10.1136/bjophthalmol-2014-305702.

2. Das A, Stroud S, Mehta A, Rangasamy S. New treatments for diabetic retinopathy. Diabetes Obes Metab. 2015 Mar;17(3): 219-30. doi: 10.1111/dom.12384. Epub 2014 Oct 6.

3. Darlow BA, Ells AL, Gilbert CE, Gole CA, Quinn GE. Are we there yet? Bevacizumab therapy for retinopathy of prematurity. Arch Dis Child Fetal Neonatal Ed. 2013 Mar; 9812:170-4. doi: 10.1136/archdischild-2011-301148. Epub 2011 Dec 30.

4. Harder BC, von Baltz S, Jonas JB, Schlichtenbrede FC. Intravitreal low-dosage bevacizumab for retinopathy of prematurity. Acta Ophthalmol. 2014 Sep;92(6):577-81. doi: 10.1111/ aos.12266. Epub 2013 Sep 11.

5. Papadia M, Misteli M, Jeannin B, Herbost CP. The influence of anti-VEGF therapy on present day management of macular edema due to BRVO and CRVO: a longitudinal analysis on visual function, injection time interval and complications. Int Ophthalmol. 2014 Dec;34(6):1193-201. doi: 10.1007/ s10792-014-0002-1. Epub 2014 Sep 23.

6. Augustine H, Munro M, Adatia F, Webster M, Fieldman M. Treatment of ocular metastasis with anti-VEGF: a literature review and case report. Can J Ophthalmol. 2014 Oct;49(5): 458-63. doi: 10.1016/j.jcjo.2014.06.008.

7. Mandić K, Vukojević N, Jukić T, Katušić D, Juri Mandić J. Changes of drusen number and central retinal thickness in agerelated macular degeneration patients over two years. Acta Clin Croat. 2016;55:354-359. doi:10.20471/acc.2016.55.03.02.

8. Kanski JJ, Bowling B. Clinical Ophthalmology: A Systematic Approach, $7^{\text {th }}$ ed. Edinburgh, New York: Elsevier Health Sciences; 2011.

9. Cheung LK, Eaton A. Age related macular degeneration. Pharmacotherapy. 2013 Aug;33(8):838-55. doi: 10.1002/phar. 1264. Epub 2013 Apr 11.

10. Resnikoff S, Pascolini D, Etya'ale D, Kocur I, Pararajasegaram R, Pokharel GP, Mariotti SP. Global data on visual impairment in the year 2002. Bull World Health Organ. 2004 Nov;82 (11):844-51. Epub 2004 Dec 14.

11. Fong DS, Ferris FL III, Davis MD, Chew EY. Causes of severe visual loss in the early treatment diabetic retinopathy study: ETDRS report no. 24. Early Treatment Diabetic Retinopathy Study Research Group. Am J Ophthalmol. 1999;127:137-41.

12. Zayit-Soudry S, Zemel E, Loewenstein A, Perlman I. Safety evaluation of repeated intravitreal injections of bevacizumab and ranibizumab in rabbit eyes. Retina. 2010;30:671-81. doi: 10.1097/IAE.0b013e3181c0858c

13. Leon PE, Saviano S, Zanei A, Pastore MR, Guaglione E, Manqoque A, Pongretto D. Spontaneous or secondary to intravitreal injections of anti-angiogenic agents retinal pigment epithelial tears in age related macular degeneration. Int J Ophthalmol. 2014 Aug 18; SA(4):681-5. doi: 10.3980/j.issn.22223959.2014.04.18. eCollection 2014.

14. Tabandeh H, Boscia F, Sborgia A, Ciraci L, Dayani P, Mariotti C, Furino C, Flynn HW Jr. Endophthalmitis associated with intravitreal injections: office-based setting and operating room setting. Retina. 2014 Jan;34(1):18-23. doi: 10.1097/IAE.0000 000000000008 .

15. Chen G, Li W, Tzekov R, Jiang F, Mao S, Tong Y. Bevacizumab versus ranibizumab for neovascular age-related macular degeneration: a meta analysis of randomized controlled trials. Retina. 2015 Feb;35(2):187-93. doi: 10.1097/IAE.00000000 00000301.

16. Velez-Montoya R, Oliver SC, Olson JL, Fine SL, Mandara N, Quinoz-Nercado H. Current knowledge and trends in age-related macular degeneration: today's and future treatments. Retina. 2013 Sep;33(8):1487-502. doi: 10.1097/IAE.0b013 e318271f265.

17. Sobaci G, Güngör R, Ozge G. Effects of multiple intravitreal anti-VEGF injections on retinal nerve fiber layer and intraocu- 
lar pressure: a comparative clinical study. Int J Ophthalmol. 2013 Apr 18;6(2):211-5. doi: 10.3980/j.issn.2222-3959.2013. 02.20 .

18. Martinez-de-la-Casa JM, Ruiz-Caho A, Saenz-Frances F, Reche-Frutos J, Caho-Gonzalez C, Donate-Lopez J, GarciaFeijoo J. Retinal nerve fiber layer thickness changes in patients with age-related macular degeneration treated with intravitreal ranibizumab. Invest Ophthalmol Vis Sci. 2012 Sep.14;53(10): 6214-8. doi: 10.1167/iovs.12-9875.

19. Horsley MB, Mandava N, Maycotte MA, Kahook MY. Retinal nerve fiber layer thickness in patients receiving chronic antivascular endothelial growth factor therapy. Am J Ophthalmol. 2010 Oct;150(4):558-61. doi: 10.1016/j.ajo.2010.04.029.

20. Shin HJ, Shin KC, Chung H, Kim HC. Change of retinal nerve fiber layer thickness in various retinal diseases treated with multiple intravitreal antivascular endothelial growth factor. Invest Ophthalmol Vis Sci. 2014 Apr 15;55(4):2403-11. doi: 10.1167/iovs.13-13769.

21. You JY, Chung H, Kim HC. Evaluation of changes in choroidal neovascularization secondary to age-related macular degeneration after anti-VEGF therapy using spectral domain optical coherence tomography. Curr Eye Res. 2012 May;37(5):438-45. doi: 10.3109/02713683.2011.647227.

22. Foxton RH, Finkelstein A, Vijay S, et al. VEGF-A is necessary and sufficient for retinal neuroprotection in models of experimental glaucoma. Am J Pathol. 2013;182:1379-90. doi: 10.1016/j.ajpath.2012.12.032. Epub 2013 Feb 12.

23. Zachary I. Neuroprotective role of vascular endothelial growth factor: signaling mechanisms, biologic function, and therapeutic potential. Neurosignals. 2005;14:207-21.

24. Tseng JJ, Vance SK, Della Torre KE, Mendonca LS, Cooney MJ, Klancnik JM, Sorenson JA, Freund KB. Sustained increased intraocular pressure related to intravitreal antivascular endothelial growth factor therapy for neovascular age-related macular degeneration.J Glaucoma.2012 Apr-May;21(4):241-7. doi: 10.1097/IJG.0b013e31820d7d19.

25. Kim YJ, Sung KR, Lee KS, Joe SG, Lee JY, Kim JG, Yoon YH. Long-term effects of multiple intravitreal antivascular endo- thelial growth factor injections on intraocular pressure. Am J Ophthalmol. 2014 Jun;157(6):1266-71. doi: 10.1016/j.ajo. 2014.02.035. Epub 2014 Feb 18.

26. Lemos-Reis R, Moreira-Goncalves N, Melo AB, Carneiro AM, Falcao-Reis FM. Immediate effect of intravitreal injection of bevacizumab on intraocular pressure. Clin Ophthalmol. 2014 Jul 23;8:1383-8. doi: 10.2147/OPTH.S64721. eCollection 2014.

27. Falkenstein IA, Cheng L, Freeman WR. Changes of intraocular pressure after intravitreal injection of bevacizumab (Avastin). Retina. 2007;27:1044-7.

28. Bakri SJ, McCannel CA, Edwards AO. Persistent ocular hypertension following intravitreal ranibizumab. Graefes Arch Clin Exp Ophthalmol. 2008;246:955-8. doi: 10.1007/s00417008-0819-2. Epub 2008 Apr 19.

29. Hollands H, Wong J, Bruen R. Short-term intraocular pressure changes after intravitreal injection of bevacizumab. Can J Ophthalmol. 2007;42:807-11.

30. Maturi RK, Bleau LA, Wilson DL. Electrophysiologic finding after intravitreal bevacizumab (Avastin) treatment. Retina. 2006;26(3):270-4.

31. Hwang DJ, Lee EJ, Lee SY, Park KH, Woo SJ. Effect of diabetic macular edema on peripapillary retinal nerve fiber layer thickness profiles. Invest Ophthalmol Vis Sci. 2014 May 15;55(7):4213-9. doi: 10.1167/iovs.13-13776.

32. van Dijk HW, Verbraak FD, Kok PHH. Decreased retinal ganglion cell layer thickness in patients with type 1 diabetes. Invest Ophthalmol Vis Sci. 2010;51:3660-5. doi: 10.1167/iovs.095041. Epub 2010 Feb 3.

33. Shahidi AM, Sampson GP, Pritchard N. Retinal nerve fiber layer thinning associated with diabetic peripheral neuropathy. Diabet Med. 2012;29:e106-e111. doi: 10.1111/j.1464-5491. 2012.03588.x.

34. Oshitari T, Hanawa K, Adachi-Usami E. Change of macular and RNFL thickness measured by stratus OCT in patients with early stage diabetes. Eye. 2009;23:884-9. doi: 10.1038/ eye.2008.119. Epub 2008 Apr 25. 


\title{
Sažetak \\ DEBLJINA SLOJA ŽIVČANIH VLAKANA MREŽNICE U GLAUKOMSKIH BOLESNIKA LIJEČENIH MULTIPLIM INTRAVITREALNIM INJEKCIJAMA ANTI-VEGF-a (BEVACIZUMABA)
}

\author{
A. Kopić, D. Biuk, J. Barać, M. Vinković, T. Benašić i V. Kopic
}

Intravitrealna aplikacija anti-VEGF agenasa za različite indikacije jedna je od najprimjenjivanijih i najbrže razvijajućih terapijskih mogućnosti posljednih godina u oftalmologiji. Najčešće se zbog svoje dostupnosti i cijene koristi bevacizumab. Eksudativna senilna makularna degeneracija (SMD) i dijabetički makularni edem (DME) među najčešćim su indikacijama za ovu vrstu terapije. Ako uz ove dijagnoze bolesnici imaju i primarni glaukom otvorenog kuta (engl. primary open angle glaucoma, POAG), imaju i stanjenje sloja živčanih vlakana PNO (lat.papilla nervi optici). U ovom prospektivnom istraživanju ispitivali smo dolazi li kod bolesnika s POAG koji moraju primati bevacizumab do dodatnog stanjenja debljine RNFL (engl. retinal nerve fiber layer). U istraživanje je bilo uključeno 60 bolesnika podijeljenih u dvije skupine. Prvu skupinu su činile oči bolesnika koji imaju eksudativnu SMD i POAG, a drugu oni koji imaju DME i POAG te su liječeni bevacizumabom. Kontrolnu skupinu činilo je drugo oko u koje nije apliciran bevacizumab. Kod svih bolesnika mjerila se debljina sloja živčanih vlakana PNO pomoću optičke koherentne tomografije kroz godinu dana, a dobivene vrijednosti su uspoređene s kontrolnim skupinama te međusobno. Rezultati su pokazali da su nakon godinu dana sve skupine imale stanjenje RNFL, ali dok u prvoj skupini nije bilo statistički značajne razlike između liječenog i neliječenog oka, u drugoj skupini je ta razlika ipak bila statistički značajna. Uspoređujući ove dvije skupine bolesnika dobiveno je statistički veće stanjenje RNFL nakon godinu dana u drugoj skupini bolesnika (DME + POAG).

Ključne riječi: Intravitrealne injekcije; Vaskularni endotelni čimbenik rasta A; Bevacizumab; Retinalna degeneracija; Makularni edem; Dijabetes melitus; Glaukom, primarni, otvorenog kuta; Hrvatska 